Corrigendum: Site-specific NMR mapping and time-resolved monitoring of serine and threonine phosphorylation in reconstituted kinase reactions and mammalian cell extracts

Francois-Xavier Theillet, Honor May Rose, Stamatios Liokatis, Andres Binolfi, Rossukon Thongwichian, Marchel Stuiver \& Philipp Selenko Nat. Protoc. 8, 1416-1432 (2013); published online 27 June 2013; corrected after print 28 0ctober 2015

In the version of this article initially published, Equation 11 was incorrect. This sign within the brackets was 'plus' and it should have been 'minus'. The error has been corrected in the HTML and PDF versions of the article.

\title{
Corrigendum: Cobalt-based nanocatalysts for green oxidation and hydrogenation processes
}

Rajenahally V Jagadeesh, Tobias Stemmler, Annette-Enrica Surkus, Matthias Bauer, Marga-Martina Pohl, Jörg Radnik, Kathrin Junge, Henrik Junge, Angelika Brückner \& Matthias Beller

Nat. Protoc. 10, 916-926 (2015); published online 21 May 2015; corrected after print 16 September 2015

In the version of this article initially published, Box 1 had the incorrect title; the correct title is 'Catalyst recycling experiments with nitrobenzene: 30 h.' The error has been corrected (for both the Box itself and the corresponding entry in the Timing section) in the HTML and PDF versions of the article.

\section{Corrigendum: The isolation and culture of endothelial colony-forming cells from human and rat lungs}

Rajesh S Alphonse, Arul Vadivel, Shumei Zhong, Suzanne McConaghy, Robin Ohls, Mervin C Yoder \& Bernard Thébaud

Nat. Protoc. 10, 1697-1708 (2015); published online 8 0ctober 2015; corrected after print 2 December 2015

In the version of this article initially published, the third author's last name was spelled incorrectly. The spelling was initially 'Zong' but should have been 'Zhong'. The error has been corrected in the HTML and PDF versions of the article. 